\title{
The International Company and Tax Avoidance
}

Viola Tanto

PhD Candidate in Tax Law, Business \& Private Law Department European University of Tirana

\begin{abstract}
In combination with sluggish economic development, the financial crisis and the debt crisis that it triggered have contributed to the fact that tax evasion, tax fraud and tax avoidance are recognized as a serious problem. Tax evasion and tax fraud by well-known personalities from politics, sport, the arts and commerce also attract intensive coverage in the media. In the companies sector, internationalization makes it easier for global corporations to shift their profits to low-tax countries and thus to minimize their tax bill. This paper shall discuss also, the measures to combat international tax evasion to be worked out by the OECD and the G20. The fact that multinational corporations are able to reduce their tax burden on profits through tax-saving plans has been known for decades. There are several reasons for the massive increase in this phenomenon in recent years. On the one hand there has been increasing globalisation, on the other corporate structures have also changed massively in recent decades. Tax havens play an important role in this context and there is practically no global player without branches in tax havens.
\end{abstract}

Keywords: tax evasion, tax avoidance, international corporate, tax heavens, profit shift.

\section{Introduction}

Tax is at the centre of the global political and business debate. The consequences of the 2007-8 global financial crisis have increased pressure on governments to fund more with less. Business practices have changed with the rise of globalisation and the digital economy and the question arises as to whether tax rules have kept pace.

Businesses function as more than simply vehicles for generating profit. It is being argued increasingly, with legislation in some cases, that profit maximisation should not be the only goal of companies. There is an increasing drive towards 'reincorporating society into corporate purpose'.

To have a better understanding of how companies are working around the tax system, we first need to understand the different tax systems in several parts of the world. There are many different opinions on the avoidance of taxes by international companies. While companies are trying to reduce their tax expenses, many believe that companies should pay their full fair share of taxes to support their governments.

into this paper we will show what authors say about the subject and the different methods that companies are using. Before getting into how companies decrease their annual tax liability, we first need to have a general idea of how corporate taxes work in different countries. There are two main types of systems implemented in the world today. The first is the transaction based system, which is used in the U.S., Canada, and Germany. In accordance with this system, except for the U.S., taxes on active business income in a foreign country are exempt from their home country corporate taxes such as company sales and service income. The US does tax all active business, income from foreign countries which leads to the taxation of income in the foreign country as well as in the US. The difference is that the U.S. allows a foreign tax credit of income that has already been paid to foreign countries to avoid a double taxation of income. This gives companies with operations in a foreign country a tax break from their US expenses.

The second type of system is used in countries such as France, Japan, and the UK. They have a jurisdiction based approach which taxes all income of foreign subsidiaries. They exempt any active business income with a local connection from home country taxation (Hines Jr., 2009). This encourages foreign investment and allows a tax break for jurisdiction based countries. They do however tax all income of subsidiaries from low tax countries, such as tax havens.

Taxation, like any type of economic regulation, must be seen not merely as a series of more or less functional decisions by 
the state and its officials, but as a dynamic and in many ways contradictory process. Business taxation, in particular, is a process primarily of negotiation between tax officials and corporate managers and advisors.

The officials, usually structured in a hierarchic bureaucracy, have the important advantage of access to state power: they can order an audit, issue an assessment to tax, publish regulations and statements of practice, or resort to the courts or legislature to clarify or amend the law. Recourse either to legal adjudication or legislative intervention depends not only on technical legal issues such as the interpretation of statute or the logic of case--law, but a variety of other factors.

The form of state regulation which most closely corresponds to a fully developed market--economy society is liberal regulation. Liberal forms of regulation require the maximum freedom for social actors to engage in economic transactions, within a framework of fixed and settled laws which enable them to choose and plan their transactions (Smith and Kinsey, 1987). Law enforcement is indirect, relying primarily on voluntary compliance, supplemented by inducements, or post facto sanctions on detected lawbreaking. The processes of legal regulation of economic relations are therefore essentially structured by markets and competition. The regulators, on behalf of the state, enforce the laws and seek to implement and develop policy, while the economic actors whose activities are regulated are free to choose and adapt their transactions. They may comply with or breach the law. More importantly, their actions may influence the patterns of development of legal relations as much as do the measures taken by regulators.

\section{Methodology}

In this article is uded a traditional legal methodology, which means that the hierarchy of the legal sources is followed.

nstead of domestic interpretation principles many states.

I will be looking at several international companies and studying their relationships with corporate tax rates. Companies continuously avoid paying taxes by using various techniques. Looking at the past, records of these companies will show the different methodologies they use to manage their way through tax laws. Governments are losing huge revenues to these tax avoidance schemes. In recent years, governments have started to track down international companies and question their various ways of tax avoidance. In this paper I will be asking the question of what are the different tax avoidance techniques that international companies use and how are different national governments trying to control them?

Besides the fact that many companies are trying to keep up with competition and continuously grow, many need to find ways to gain an advantage over the competition. To increase revenue and expand on profits, companies need to find ways to avoid paying unnecessary expenses. By moving their operations overseas, corporations largely reduce, or avoid paying altogether, corporate taxes. Corporate taxes play a vital role in governmental revenue generation, however, by reducing corporate taxes, multinational companies gain an enormous advantage over their competitors and greatly increase their after tax profits. There are many different ways multinationals do this which we will look at.

Looking at the different tax laws regarding the taxation of multinational companies shows how these companies avoid paying taxes on the international scale. Though they play an important role in government revenue generation, corporate taxes are avoided in many different ways by multinational companies to increase their income and reduce their expenses. Through the examination of company tax payments we will see how much they actually pay in taxes and the various implementations they use to avoid the payment of corporate taxes.

\section{Concepts and Issues of International Tax Evasion and Avoidance}

Various features of the globalized economy have enabled an increasing number of individuals and companies to resort to tax evasion or tax avoidance. These features include the ease and rapidity of communications, the progressive elimination of obstacles to the movement of persons and property, the expansion of international economic relations, the differences in national tax systems and hence in the tax burden from country to country, and the growing sophistication and aggressiveness of taxpayers and their advisers in developing legal and illegal techniques for taking advantage of weaknesses in national tax systems.

The terms "tax evasion" and "tax avoidance" (Maurice H. Collins, 1988) have not always been used precisely or with a uniform meaning. Tax evasion is usually associated with the commission of a criminal offense. It can be considered to consist of wilful and conscious non-compliance with the laws of a taxing jurisdiction which can include a deliberate concealment of facts from revenue authorities. Tax evasion is an action by which a taxpayer tries to escape legal obligations by fraudulent or illegal means. It may result from the evasion of tax on income that arises from illegal activities, such as 
smuggling, drug trafficking, and moneylaundering. Some xamples of tax evasion include:

- The failure to notify the taxing authorities of one's presence in the country if he is carrying on taxable activities;

- The failure to report the full amount of income;

- Deductions of claims for false expenses;

- Falsely claiming relief that is not due;

- The failure to pay over the proper amount of tax due;

- Departing from a country without paying a tax due with no intention of paying them;

- The failure to report items or sources of taxable income, profits or gains where there is an obligation to provide such information or if the taxing authorities have made a request for such information.

Tax avoidance is not tax evasion. In contrast, It involves the attempt to reduce the amount of taxes otherwise owed by employing legal means. According to (Palumbo, 2011), tax avoidance occurs when persons arrange their affairs in such a way as to take advantage of weaknesses or ambiguities in the tax law. Although the means employed are legal and not fraudulent, the results are considered improper or abusive. Because of the subjectivity of the interpretation and application of tax avoidance the borderline between evasion and avoidance in specific cases may be difficult to define. For one thing, the criminal laws of countries differ, so that behaviour that is criminal under the laws of one country may not be criminal under the laws of another. In addition, the definitions of civil and criminal tax fraud may overlap, so that it is within administrative discretion whether or not to pursue a criminal fraud case in a specific instance. In reality, there is a continuum of behaviour, ranging from criminal fraud on one extreme, to civil fraud, to tax avoidance that is not fraudulent but which runs afoul of judicial or statutory anti-avoidance rules and therefore does not succeed in minimizing tax according to law, and finally to tax-planning behaviour which is successful in legal tax reduction.

Tax avoidance is defined as all practices of individuals and organisations which are intended to avoid the payment of taxes, whereby:

-tax laws are not formally contravened, discerning tax avoidance from tax evasion which implies the use of illegal practices;

-the intentions of tax laws are violated, i.e. loopholes in tax laws are used to obtain tax advantages that the government never intended;

-transactions do not follow logically from the economic "substance" (assets, employees, revenues, etc.) of the company but are set up with the purpose to reduce tax liability.

Courts in most countries have consistently recognized the right of taxpayers to avoid taxes by means that are within the law. However, courts in many countries have also found that the tax laws should be interpreted so as to prevent their avoidance by the use of transactions that have no business purpose, although there is considerable variety in the approaches of courts in different countries. Tax avoidance typically involves four basic techniques:

- Deferred payment of tax liability;

- Re-charicterization of an item of income or expense to tax at a low rate;

- Permanent elimination of tax liability, and

- Shifting income from a high taxed person to a low taxed person.

These goals can be accomplishes through the use of international tax shelters through artificial intermediary companies; excessive use of debt over equity; and non-arm's length transactions.

Depending on the existence of judicial or statutory anti-avoidance rules, tax avoidance may or may not be successful if a case is audited and litigated. To apply antiavoidance rules, the tax authorities typically must discover the relevant transaction in a tax audit and obtain and analyse the information necessary to apply the anti-avoidance rules, that in a cross-border situation, it may be difficult.

Globalization and the removal of impediments to the free movement of capital and exchange controls have promoted 
sustainable economic development. However, they have also increased the scope for tax avoidance and evasion with consequential substantial loss of revenue. International tax avoidance and tax evasion cause many problems. Governments lose significant amounts of revenue and hence the honest taxpayers who do not escape their liability to pay tax must bear an additional burden to plug the gap.

Tax authorities in the Member States of the OECD have responded to concerns about avoidance and evasion by taking on new powers to collect information from taxpayers ${ }^{1}$.

\section{Tax Avoidance Through Low-Tax Jurisdictions}

In general terms, a low-tax jurisdiction can be defined as a jurisdiction which imposes little or no tax on companies, trusts or other entities organized there. By forming a company in such a jurisdiction and arranging for that company to derive income from third countries, a multinational enterprise may be able to shelter income from taxation both at the source and in its residence country. By forming a holding company or a trust in a tax haven, an individual or institution may similarly be able to shelter investment income from taxation. The OECD has distinguished between two types of low-tax jurisdictions those that simply offer a low-tax environment and those it has identified as "non-cooperative jurisdictions". The OECD has sought to combat the threat of non-cooperative jurisdictions to the legitimate tax-policy objectives of its Member States by putting economic pressure on those jurisdictions to cooperate in the prevention of tax fraud and evasion.

Non-cooperative jurisdictions may be defined as jurisdictions which do not participate in effective exchange of tax information between tax authorities. A lack of effective exchange of tax information may occur where bank secrecy or other laws prohibit the disclosure of information concerning financial transactions carried out in the country, or where there is inadequate information available regarding the beneficial ownership of accounts, financial instruments and other assets held in the country. A multinational enterprise may be able to shelter income from taxation both at source and in its residence country by forming a company in a non-cooperative jurisdiction which has lower or no tax on relevant income. Similarly, an individual may be able to shelter income by forming a holding company or trust in a noncooperative jurisdiction which has lower or no tax on relevant income. Examples of both tax avoidance and evasion are as follow.

\section{Practices resorted to in order to reduce taxes imposed on international income}

These practices, fall into four categories: a) practices resorted to in order to reduce income taxes imposed by the country of residence or citizenship; b) practices resorted to in order to evade or avoid taxes imposed by the country of source; c) institutional devices and arrangements that facilitate the evasion or avoidance of taxes imposed on international income; and d) the use of related tax-haven entities to reduce such taxes.

\section{Practices resorted to in order to reduce taxes imposed by the country of residence or citizenship}

Many countries impose taxes on income received from abroad by residents or nonresident citizens. The practices resorted to in order to reduce payment of these taxes include the following:

Failure to file a return- One of the most common practices resorted to in order to reduce payment of taxes on international income consists in the deliberate failure of resident aliens to file tax returns in the country in which they are residing. Persons who spend a portion of each year in each of two or more jurisdictions often make inconsistent claims of residence. When a country taxes the worldwide income of its citizens, a citizen who is residing abroad may fail to file a return in the country of his citizenship.

Failure to report all income subject to tax- Another important practice in this category is the wilful or negligent failure to report all items of international income that are subject to tax. The items most often omitted are salaries, wages and noncommercial income, interest and dividends, business income, income from real estate, gains on the disposition of property and royalties.

\section{Salaries, wages and non-commercial income}

\footnotetext{
1 Ways of increasing compliance in cross-border financial transactions and on access to bank information for tax purposes are the focus of current work. Additional work will also be carried out to identify and address other barriers to the identification of beneficial ownership and exchange of such information. The OECD Model Convention contains an article on exchange of information. Current work to improve exchange of information includes looking not only at barriers to effective exchange of information but also at how better use of the latest information technology can help. OECD countries have adopted a standard magnetic format for exchange of information. 
Persons receiving remuneration from abroad in payment for services, in the form of pensions and annuities frequently fail to report this income in tax returns to their country of residence. Consequently, such income, if not taxed at the source, is apt to escape taxation both in the country where it is acquired and in the country in which the recipient is resident.

\section{Interest and dividends}

In the view of many tax administrators, tax evasion or avoidance is probably most prevalent in connection with this type of income, since interest and dividends can easily be collected anonymously at a financial institution in a third country where the securities are held in custody. This type of income also lends itself to many fraudulent practices through the skillful use of certain special provisions of domestic laws. Thus, certain institutions whose prime purpose is economic or financial are frequently used to facilitate tax evasion or avoidance.

\section{Business income}

Taxes on business income are reduced at times by means of deliberate failure to keep accurate books and records within the taxing jurisdiction. A second set of books, which is accurate, may be maintained outside the taxing jurisdiction, and beyond the reach of the authorities of that country. In some instances, the maintenance of false books within the taxing jurisdiction is facilitated by limitations in domestic law on the extent to which the taxpayer's books and records may be examined by the tax authorities. Business profits properly allocable to the source country may be shifted to other countries by such devices as the establishment of artificial transfer prices for imports and exports, the improper allocation of costs, and licensing agreements under which the user of technology isobliged to purchase imported inputs, equipment and spare parts at inflated prices. Such devices, which transnational corporations are particularly well situated to use, are of great concern to developing countries, whose tax officials often lack the time and expertise to challenge effectively the prices set between affiliated companies.

\section{Thin capitalization}

Many countries allow corporations to take a deduction for interest expenses but do not allow a deduction for the payment of dividends. This differential treatment of interest and dividends creates a bias in favour of debt finance over equity finance. The bias is particularly strong when the dividends or interest would be paid to an affiliated company. For example, if Company A owns all the stock of Company B, it is generally indifferent, aside from tax considerations, as to whether it receives dividends of interest payments from Company $B$. To prevent corporate taxpayers from distributing their profits to their parent corporation mostly in the form of deductible interest, many countries have adopted so-called "thin capitalization" rules. Under these rules, a corporation that has what is deemed to be an excessive amount of debt capital will be prevented from taking a deduction for payments made with respect to that excessive debt capital. The amount of debt capital of a corporation typically would be characterized as excessive if the ratio of debt to equity exceeded some number.

\section{Royalties}

Royalties paid abroad for the use of or the right to use patents, trademarks, know-how or other intangible property may be used to shift profits out of high-tax countries into low-tax or into no-tax countries by fixing the royalties at artificially high rates. Such devices are facilitated by difficulties in estimating the arm's length value of monopoly rights. In addition, multinational firms may transfer intangible property to an affiliated corporation under conditions that would not occur between unrelated persons. For example, a multinational corporation might transfer highly profitable know-how that it would never share with an unrelated person to a corporation organized in a tax haven simply for the purpose of generating a deduction in the country where the intangible property is located.

\section{Technical assistance}

Affiliated corporations may charge improper technical fees as a way of minimizing taxes for the corporate group. In some cases, they may set the fees too high. For example, a corporation engaged in business in a country may pay an excessive technical assistance fee to a related corporation located in a low-tax jurisdiction in order to take an excessive deduction. The source country may have difficulty determining a proper price for technical assistance because those services tend to be unique and difficult to value. In other cases, a corporate group may set the technical assistance fees too low. For example, a foreign corporation making sales of goods into a country may provide technical assistance in conjunction with those sales. Under its tax treaty, the sales income would be exempt if the foreign corporation has no permanent establishment in the country, whereas the fees for technical assistance may be the subject to a withholding tax. To minimize the withholding tax, the foreign corporation may claim that the technical assistance has little value. 
9. In a variety of circumstances, a taxpayer may claim fictitious or inflated business expenses as deductions. In employing this tactic, the taxpayer may claim that the purported payment was made to a person located outside the taxing jurisdiction, thereby making an audit of the expenses difficult for the tax authorities. For example, if the taxpayer purchases goods outside the taxing jurisdiction, false invoices may be prepared to show a purchase price greater than the actual amount paid by the taxpayer.

Tax may be reduced by improperly characterizing an income or expense item in order to make use of an exemption or reduced rate. Where taxation is based on a temporary status, tax evasion or avoidance may occur through transactions that take advantage of that temporary status. For example, because a borrower is not liable to tax on the proceeds of a loan, a foreign national may arrange an ostensible loan while he is a resident of the taxing jurisdiction, and then sell the collateral for the alleged loan to the lender following his departure from the taxing jurisdiction (when he is no longer taxable on sales profit within that jurisdiction), with the "loan" being credited against the sale price.

\section{Foreign holding companies and trusts}

Under the laws of some countries, a resident may legally avoid tax by placing income producing property in a foreign corporation or trust which he controls. Under the laws of other countries, the investment income is taxable by the country of residence whether or not it is actually distributed by the foreign corporation or trust to the resident owner.

\section{Artificial bank loans}

A major technique for international tax evasion consists of purportedly borrowing funds that are actually owned by the borrower. This practice not only enables the "borrower" to make open use of funds previously concealed in the name of a nominee or in a numbered bank account, but it also gives the borrower a pretext for claiming fictitious interest deductions.

\section{Use of related tax-haven entities to reduce taxes}

Taxpayers sometimes utilize entities organized in tax-haven countries to reduce taxes legally, the legality of the transactions depending on the laws of the country where taxpayers are located. The presence of tax-haven countries, however, invites tax evasion activities that initiate essentially false or illegal relationships with the tax-haven country. Some of the latter situations are described below.

\section{i. Transfer of income-producing assets to a tax-haven entity}

ii. Nominal transfer of income-producing functions to a tax-haven entity

iii. Payment of deductible expenses to a tax-haven entity (such as management fees, technical service fees, or other deductible fees).

Some of the techniques described above may be legal methods of reducing tax, rather than illegal methods of evading tax, depending on the law of the particular countries involved.

\section{Legislative and Judicial Anti-Avoidance Measures}

The manner in which tax avoidance can be met can include legislative and judicial response. In some cases a jurisdiction will enact specific provisions that identify the type of transaction to be dealt with and prescribe specific legislative remedies to combat such avoidance.

Another legislative method would be to enact broad types of avoidance practices in specific areas or to control tax avoidance through the discretion of the tax authorities.

Finally requiring related parties treat transaction in the same manner as independent parties can be another response. Most jurisdictions rely on specific anti-avoidance rules in their domestic legislation and judicial case law.

Where the legislative response to tax avoidance has been ineffective court have developed judicial doctrines to counter serious cases of tax avoidance. These judicial decisions tend to be more flexible than statutory rules under the domestic law and often overlap with each other.

Common judicial doctrines are derived from common law and include:

- Business Purpose Rule-the business purpose rule attacks avoidance transactions which have no business purpose and 
are created to avoid taxes;

- Substance of Form- Under the substance over form principle, the facts must be assesses according to bona fide substance and not formal content;

- Sham Transactions- a sham transaction conceals the true nature of a transaction that exist in form only;

- Doctrine of the Label- the parties use the wrong label or description to classify or characterize a transaction or relationship for tax purposes;

- Step Transaction Doctrine- in a step transaction, the intermediate steps in a chain of predetermined transactions may be disregarded and several related transaction may be treated as one integrated transaction. Alternatively the transaction may be broken up into its distinct steps to determine their acceptance for tax purposes.

The step transaction doctrine maintains that "purely formal distinctions cannot obscure the substance of the transaction".

- Abuse de droit ("Abuse of Right") - An abuse of right is the manipulation of the intention or spirit of the law in such case the court will disregard the legal form where the transaction is undertaken solely or predominantly to avoid tax without a bona fide business purpose;

- Fraus Legis ("Abuse of Law") the fraus legis principle allows a court disregard a transaction entered for tax avoidance purposes and to substitute it by a "normal" transaction. The tax is imposed as if the taxpayer did not carry out the "disregarded" transaction but a similar taxable transaction.

- Simulation- Certain civil law countries apply the doctrine of simulation to ensure "substance over form."

- Mutual administrative assistance- Tax treaties are stipulating assistance in collecting taxes. Such an article would have two main advantages: it increases the chance of collecting taxes from taxpayers living abroad and it reduces tax evasion possibilities through emigration. It goes without saying that a State has to be sure that the aim of assistance in collection of taxes is suitable and desirable within its treaty policy before it inserts such a provision in a treaty.

A State which wishes to introduce such an article has to consider at least the following issues. In the first place, a State needs to possess a legislative framework which allows theimplementation in practice of this provision. Secondly, the tax administration should be capable and able to collect the tax revenues. Furthermore, it should be considered whether the mutual advantages would justify the new obligations between the two Contracting States.

The Multilateral Convention generally requires that each Contracting State provide administrative assistance in tax matters to each other Contracting State. The Convention provides for three basic categories of assistance, with regard to a wide range of taxes: exchange of information, assistance in the collection of taxes, and service of documents.

\section{Conclusions and Recommendations}

State taxation begins from the primary purpose of raising money for the treasury. In that sense, it always involves a political choice which affects differently specific individuals or groups, i.e. a collective decision to deprive some of wealth for the benefit of others or for the common good. However, in a society where market relations are dominant, the dominant considerations are those of liberalism: that the tax burden should fall equally on all and that its enforcement should interfere as little as possible with private economic activity. These were classically expressed in Adam Smith's four canons of taxation: equality, certainty, convenience and economy (Smith \& Kinsey, 1987).

The notion of equality, however, is clearly problematic, since it involves attempting to treat as equal legal subjects social actors who may be economically quite unequal. Smith's general notion was that citizens should contribute to the treasury in proportion to the revenues they enjoy under the protection of the state. His principle therefore favoured the direct taxation of the incomes of all citizens, rather than specific levies such as stamp duties or window--tax, which were unrelated to ability to pay.

The principle of ability to pay and the view that a uniform rate bears unfairly on those with middle and low incomes justifies progressively higher rates on higher bands of income, sometimes referred to as equity.

Should business or corporate profits be treated as income and taxed on the same principles as individual income, so that the sole trader, the partnership and the company are taxed in the same way? Is there a clear and valid distinction between 
income and capital gain? Underlying all these questions is the definition of income itself, the tax base, which is at the heart of the operation of direct taxes. It is also at the heart of the problem of avoidance.

Taxation is not an Abstract exercise in political or economic philosophy, but a practical matter of raising state finance for the public good. The overriding aim is therefore effectiveness, which must be predicted, based on estimations of the patterns of compliance, non--compliance and avoidance. It is in this sense that the question of legitimacy is central to the evaluation of taxation, as well as other types of legal regulation of economic activity. Legitimacy in this sense combines the interrelated issues of equity and effectiveness. To the extent that a regulatory system lacks fairness it fails in political acceptability, and will also tend to fail in effectiveness as enforcement becomes difficult and noncompliance grows. Equally, a system which has problems of enforceability and therefore of effectiveness will tend to lose political acceptability.

Governments need tax payments to stimulate national prosperity, welfare and an equitable economic development. Only through levying taxes they can fund facilities such as infrastructure, education, healthcare and a social safety net. Companies can contribute to these public facilities by paying a fair amount of tax. All countries, but especially developing countries need additional income to realise the mentioned facilities, and it is a heavy burden that companies and wealthy individuals avoid taxes on a large scale.

Tax avoidance is a problem for everyone and provides relatively little benefits. This is the case for both poor and rich countries, and for both citizens and small and medium-sized enterprises. The premise of this study is that companies should pay taxes where their economic activities take place. Taxation should be based on the nature and scope of the economic activities (the substance) which companies have in each jurisdiction they are active in, in accordance with the applicable tax regulations in these jurisdictions. Individuals with large financial wealth should also pay their fair share of taxes.

International transactions between companies which are based in different jurisdictions but belong to the same business group, offer many options for tax avoidance schemes. Multinationals can reorganize their financial flows (payments for goods and services, dividends, interest payments, etc.) and set up foreign subsidiaries which undertake no real economic activities, for the sole purpose of utilizing the differences in tax rates and regulations between jurisdictions. With such transactions often no tax laws are violated officially. Nevertheless, the tax regulations and tax rates in one jurisdiction are undermined by making use of more favourable tax regulations in another jurisdiction.

In many international tax avoidance structures tax havens play a prominent role. Tax havens are jurisdictions which have a legislative environment which provides opportunities to individuals and/or companies domiciled elsewhere to evade or avoid taxes due in other jurisdictions. Classic tax havens generally offer very low income tax rates and no withholding taxes, in combination with very limited disclosure requirements for companies and limited exchange of fiscal data with other jurisdictions. Tax-treaty jurisdictions generally have concluded tax treaties with many countries and have very low withholding tax rates, enabling financial flows to pass through the jurisdiction easily. In these jurisdictions, income taxes usually have a normal level and transparency is higher than in classic tax havens.

The manner in which tax avoidance can be met can include legislative and judicial response. In some cases a jurisdiction will enact specific provisions that identify the type of transaction to be dealt with and prescribe specific legislative remedies to combat such avoidance.

Another legislative method would be to enact broad types of avoidance practices in specific areas or to control tax avoidance through the discretion of the tax authorities.

Companies should be more transparent and act responsibly when making decisions that possibly could lead to forms of international tax avoidance. They should compy to the fullest extent possible to the OECD Guidelines for Multinational Enterprises' chapter about taxation, which says, "Corporate citizenship in the area of taxation implies that enterprises should comply with both the letter and the spirit of the tax laws and regulations in all countries in which they operate, co-operate with authorities and make information that is relevant or required by law available to them," as well as measures following from the ongoing OECD initiative against base erosion and profit shifting (BEPS).+ 


\section{References}

[1] Antonini L., 1966, Equivalenza di fattispecie tributarie ed elusione di imposta, Riv. dir. Fin.

[2] Amatucci F., 2009, L'abuso del diritto nell'ordinamento tributario nazionale, Clausola generale antielusiva, Corriere giuridico.

[3] Brown Karen B., A comparative look at regulation of corporate tax avoidance, Comparative prespectives on law and justice,12, Springer editor, p.p 1-5.

[4] De la Feria R. \& Vogenauer S., 2011, Prohibition of Abuse of Law, A New General Principle of EU Law?, Studies of the Oxford Institute of European and Comparative Law.

[5] Ivo Caraccioli, 2009, Elusioni o forzature nell'applicazione dell'imposta di registro, Gianni Marongiu; Spunti di metodo in tema di "abuso del diritto", Paolo Gentili; Neotepa- Periodico ufficiale dell'A.N.T.I. - Associazione Nazionale Tributaristi Italiani, Milano.

[6] Cowell, F. A. (1992). "Tax Evasion and Inequity. " Journal of Economic Psychology 13, 521-543.

[7] Galdieri E., 2009, General anti-avoidance rules \& doctrines, EUCOTAX Wintercourse 2009, Barcelona, Università LUISS - "Guido Carli" - Roma, Facoltà di Giurisprudenza, Cattedra di Diritto Tributario.

[8] Garbarino C., 2009, The development of a judicial anti-abuse principle in Italy, British Tax Review, B.T.R.

[9] Lavoisier, 2099, L'abuso di diritto nell'ordinamento tributario italiano.

[10] Losurdo F., 2011, Il divieto dell'abuso del diritto nell' ordinamento europeo, storia e giurisprudenza, G.Giappicheli Editore, Torino.

[11] Maurice H. Collins, 1988, Evasion and Avoidance of Tax at the Unternational Level (Eurpoean Taxation, September 1988)

[12] OECD Guidelines and OECD Model Convetions

[13] Orow Nabil BEc, LLB (Hons), 2000, Department of Business Law and Taxation, Faculty of Business and Economics, Monash University, Victoria, Australia, General anti-avoidance rules, A comparative International analysis, Jordans Editor, Bristol.

[14] Palumbo G., 2011, Elusione fiscale e abuso del diritto, L'aggiramento degli obblighi impositivi tra legittimo risparmio ed evasione fiscale, Cesi Multimendia, Milano, 1-3.

[15] Piantavigna P., 2011, Abuso del diritto fiscale nell' ordinamento europeo, G.Giappicheli Editore, Torino.

[16] Pistone P., 1995, Abuso del diritto ed elusione fiscale, Padova, p.p 7-8.

[17] Picciotto, S., 2015, A Study in the Internationalization of Business Regulation, Emeritus Professor, University of Lancaster

[18] Smith, K. W. and K. A. Kinsey. (1987). "Understanding Taxpaying Behavior: A Conceptual Framework with Implications for Research. " Law and Society Review 21(4), 639-663

[19] Terracina D., 2012, Riflesi penali dell' evasione fiscale, Tra ricchezza nascosta e regime del dichiarato, Dike Giuridica Editrice, Roma, 183-190. 